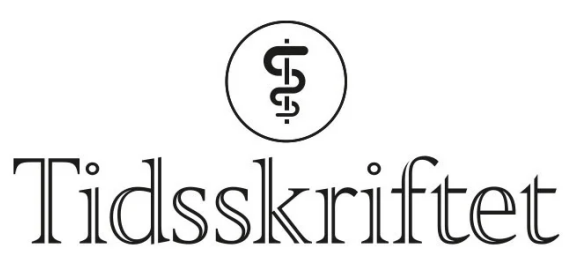

DEN NORSKE LEGEFORENING

\title{
Risiko for brystkreft ved hormonbehandling i klimakteriet
}

ORIGINALARTIKKEL

\section{SARAH SATHER}

Sarah Sæther (f. 1988) er student ved forskerlinjen i medisin, Universitetet i Troms $\emptyset$. Forfatter har fylt ut ICMJE-skjemaet og oppgir ingen interessekonflikter. Email: sarah.sather@uit.no

Forskerlinjen i medisin

\section{KJERSTI BAKKEN}

Kjersti Bakken (f. 1950) er cand.pharm og førsteamanuensis ved Institutt for samfunnsmedisin, Universitetet i Tromsø. Hun har skrevet doktorgrad rundt dette temaet. Forfatter har fylt ut ICMJE-skjemaet og oppgir ingen interessekonflikter. Institutt for samfunnsmedisin Universitetet i Troms $\emptyset$

\section{EILIV LUND}

Eiliv Lund (f. 1947) er professor ved Institutt for samfunnsmedisin, Universitetet i Troms $\varnothing$ Forfatter har fylt ut ICMJE-skjemaet og oppgir følgende interessekonflikter: Instituttet har mottatt penger fra ERC TICE-prosjektet for mikromatriseanalysene kjøpt ved NTNU.

Institutt for samfunnsmedisin

Universitetet i Troms $\emptyset$

\section{BAKGRUNN}

. Kvinner og kreft-studien har vist at relativ risiko for brystkreft ved hormonbehandling med kombinasjonspreparater utover fem år var nær tredoblet. Tilskrivbar risiko i befolkningen var $27 \%$. I en nøstet pasient-kontroll-studie har vi oppdatert risikoestimater for hormonbehandling hos postmenopausale kvinner etter 2002.

\section{MATERIALE OG METODE.}

Vi plukket en aldersparet kontrollperson til hver av de 589 kvinnene (46-63 år) som i 2004o8 fikk påvist invasiv brystkreft eller cancer in situ. I 2003-06 besvarte disse et spørreskjema om bl.a. menstruasjonsforhold og bruk av hormonbehandling. Opplysningene fra dette og tidligere spørreskjema ble sammenstilt og analysert med logistisk regresjon.

\section{RESULTATER.}


$226(26 \%)$ av kvinnene brukte hormonbehandling på tidspunktet for spørreskjemaundersøkelsen. Gjennomsnittlig brukslengde var ti år. Nåværende brukere hadde høyere risiko for brystkreft enn aldri-brukere (justert OR 2,1; $95 \% \mathrm{KI}$ 1,5-3,0). Bruk av kombinasjonsbehandling utover fem år ga høyest risiko (OR 3,0; $95 \% \mathrm{KI}$ 1,9-4,7). Tidligere bruk av østrogenpreparater ga ingen forhøyet risiko. Østradiol eller tibolon ga ikke statistisk signifikant $\varnothing$ kt risiko. 232 brystkrefttilfeller (17\%) hos kvinner 45-64 år kunne tilskrives hormonbruk.

\section{FORTOLKNING}

Langvarig bruk av kombinasjonspreparater gir økt brystkreftrisiko. Relative risikoestimater har endret seg lite fra forrige studie, mens tilskrivbar risiko i befolkningen har sunket med færre nye brukere.

\section{Tabell}

\begin{tabular}{|l|}
\hline Hovedbudskap \\
\hline utover fem år \\
- $\quad$ Tilskrivivbar risiko i befolkningen har sunket i tråd med nedgangen i nye brukere \\
- Blant etablerte brukere er gjennomsnittlig brukstid ti år \\
- Behandlingsvarighet nær ti år gir grunn til bekymring, fordi eldre kvinner allerede har \\
forhøyet risiko
\end{tabular}

Klimakteriet er tiden rett før og etter menopause, som markerer slutten på kvinnens fertile periode. Menopausen er en naturlig fase i kvinners liv, men fikk i 1960- og 70-årene mer status som en mangelsykdom som måtte behandles med hormoner. Publisering av bøker som Feminine forever i USA (1) og Alltid kvinne (므) her hjemme samt aktiv markedsføring fra legemiddelfirmaenes side bidro til dette. Det ble hevdet at menopausen representerte en "kastrasjon» av kvinnen som kunne forhindres ved bruk av hormoner. I tillegg til å bevare ungdommelighet og "sex appeal», hevdet man at hormonbehandling kunne forebygge depresjon, ulike smerter, hjertesykdom og demens hos kvinnene. Vitenskapelige studier i 1980- og 9o-årene bidro også til at dette virket sannsynlig (3). Det var kjent at hormonbehandling effektivt forebygger osteoporose (4). Sammenhengen mellom $\emptyset$ øtrogenbruk og økt risiko for brystkreft ble rapportert allerede i 1976 (5), men det var resultatene fra og medieoppslagene etter Women's Health Initiative-studien i USA (므) som førte til en markant salgsnedgang for østrogener. I den randomiserte, kliniske studien fant man en signifikant økt risiko for brystkreft hos de som fikk østrogen og progestagen, sammenliknet med placebogruppen. Risiko normaliserte seg når behandlingen ble avsluttet. Også den britiske kohortstudien The Million Women-studien bekreftet sammenhengen (7.).

En studie fra Kvinner og kreft-kohorten, med data fra 31451 norske postmenopausale kvinner i alderen 45-64 år, viste at relativ risiko (RR) for brystkreft var 2,1 (95\% KI 1,7-2,7) ved nåværende østrogenbruk. Kohorten ble fulgt fra 1996 t.o.m. 2002, da salgsnedgangen startet. Tilskrivbar risiko, dvs. andelen av brystkreftforekomsten som kan tilskrives østrogenbruk, ble beregnet til $27 \%$. Langvarig bruk (> 5 år) av kombinasjonspreparat ga størst risiko (RR 2,8; $95 \% \mathrm{KI}$ 2,0-4,0) (ㅁ). Norske tall viser at salget av hormonpreparater til 
systemisk bruk ble redusert med over 45 \% fra 2001-05 og er nå på 1990-nivå (9.). Figur 1 viser salgskurven for hormonpreparater samt årlig brystkreftinsidens blant norske kvinner i aldersgruppen $45-64$ år.

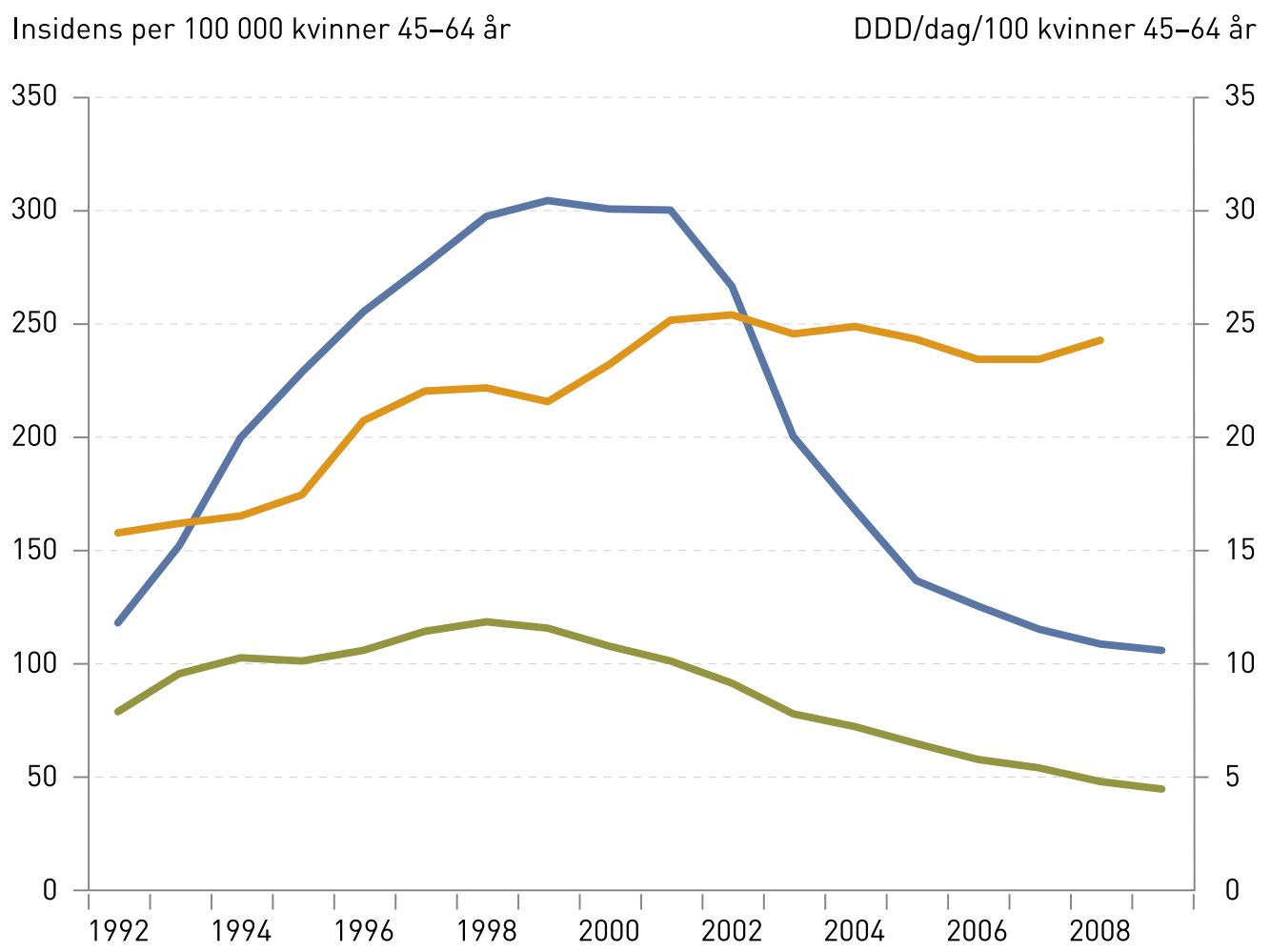

Østradiol, tibolon, kombinasjoner Østriol Brystkreftinsidens

Figur 1 Brystkreftinsidens og salg av hormonpreparater 1992-2009. Salg av hormonpreparater oppgitt som definerte døgndoser (DDD) per dag per 100 kvinner. Tallene er basert på grossistsalg til apotek (E. Eriksen, Reseptregisteret, Nasjonalt folkehelseinstitutt, personlig meddelelse) og befolkningstall fra Statistisk sentralbyrå. Brystkreftinsidens blant norske kvinner i alderen 45-64 år er utlevert fra Kreftregisteret (personlig meddelelse O. Talleraas, Kreftregisteret). Kreftregisteret er ikke ansvarlig for presentasjonen eller tolkingen av tallene

En studie av bruksmønster hos kvinnene fra Kvinner og kreft-studien etter 2002 viser en tendens til økt behandlingslengde blant dem som allerede er brukere, mens tilveksten av nye brukere har gått ned (10 $)$.

Vi har foretatt en nøstet pasient-kontroll-studie fra Kvinner og kreft-studien, med oppfølging for brystkreft eller cancer in situ fra 2004-08. Formålet med studien var å beregne risiko for brystkreft samt tilskrivbar risiko ved bruk av systemisk hormonbehandling. Vi ønsket også å se om risikoestimatene har endret seg siden 2003.

\section{Materiale og metode}

Kvinner og kreft er en prospektiv studie av 172 ooo tilfeldig utvalgte norske kvinner (1ㅡ). Kvinnene har besvart ett til tre spørreskjema om bruk av hormoner, menstruasjonsforhold, reproduksjonshistorie, sykdom og kreft i familien samt livsstilsvaner som kosthold, røyking, fysisk aktivitet, alkoholinntak og soleksponering. Kvinnene følges opp kontinuerlig for brystkreft via koblinger til Kreftregisteret.

I forbindelse med studien finnes også en biobank med blodprøver fra 50 ooo av kvinnene i alderen 46-63 år, samlet inn i perioden 2003-06. Blodprøvene er tatt ved kvinnenes lokale legekontor og sendt i posten sammen med et tosidig spørreskjema om 
menstruasjonsforhold, matinntak, røyking, vekt og høyde, bruk av medisiner, hormoner og kosttilskudd og alkoholinntak (blodskjema). Biobanken utgjør den postgenome delen av

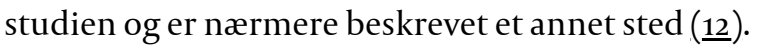

Fra 2004 til utgangen av 2008 ble det registrert 473 tilfeller av invasiv brystkreft og 116 carcinoma in situ i den postgenome kohorten. For hvert tilfelle ble det trukket en kontrollperson som samsvarte i alder og tidspunkt for blodprøvetaking. Bakgrunnen for denne parvise samsvaring er en genekspresjonsstudie med mikromatriseanalyse av blod. Vi inkluderte kun postmenopausale kvinner i studien ( 358 med invasiv brystkreft, 83 med carcinoma in situ, 451 kontrollpersoner). Informasjon fra blodskjema og tidligere spørreskjema ble koplet sammen til et datasett.

Kvinner og kreft-studien er godkjent av den regionale komité for medisinsk og helsefaglig forskningsetikk i Nord-Norge. Alle prøver og data er lagret og håndtert i henhold til tillatelsen fra Datatilsynet.

\section{MENSTRUASJONSSTATUS}

Kvinnenes menstruasjonsstatus ble fastsatt ut fra opplysninger i blodskjema og tidligere spørreskjema. De ble klassifisert som premenopausale hvis de svarte «ja» på spørsmål om de hadde menstruasjon, postmenopausale om de svarte «nei» eller hadde uklart svar og var over 53 år, og perimenopausale dersom de krysset av for «uregelmessig». Kvinner som hadde fått hysterektomi, brukte hormoner, eller hadde uklart svar og var under 53 år fikk status «usikker».

\section{BRUK AV HORMONBEHANDLING}

Kvinner som i blodskjema oppga bruk av et østrogenholdig preparat i løpet av den siste uken ble satt som nåværende brukere. Det ble ikke skilt mellom sekvenspreparater og preparater med kontinuerlig tilførsel av progestagen. Fra forutgående spørreskjema sjekket vi om kvinnene også tidligere hadde benyttet østrogenpreparater. Dersom kvinnen hadde svart «ja» på hormonbruk i overgangsalder, uavhengig av hvilket spørreskjema, ble hun klassifisert som bruker «noen gang». Hvis kvinnen var «noen gang»-, men ikke «nåværende»-bruker, ble hun satt som bruker «før». Opplysning om alder ved start av behandling ble brukt til å beregne total varighet av bruk. Vi forutsatte da at kvinnene fortsatte behandlingen i perioden mellom de to spørreskjemaene. Tiden fra siste spørreskjema til blodskjema var i gjennomsnitt ett år. Kvinner som svarte nei på spørsmålet om bruk i begge spørreskjemaene, ble satt som aldri-brukere.

\section{DATABEHANDLING}

Kontroller med samme fødselsår og tidspunkt for blodprøvetaking er trukket tilfeldig blant kvinnene i kohorten. Transformering av variabler og logistisk regresjon ble utført med SPSS versjon 17,o. Vi justerte for alder, kroppsmasseindeks, alder ved menarke, brystkreft hos mor, paritet, alder ved første fødsel og tidligere bruk av hormonbehandling. Alle variablene er forventet å ha en effekt på risikoen for brystkreft.

\section{Resultater}

I alt 892 kvinner ble inkludert. Åtte kvinner som anga bruk av hormonbehandling ble ekskludert fra analysene fordi navn på preparat ikke var nevnt. En karakteristikk av kvinnene finnes i tabell 1.

\section{Tabell 1}

Karakteristikk for pasienter og kontrollpersoner

\begin{tabular}{|lcccc|}
\hline & \multicolumn{2}{c|}{ Pasienter $(\mathrm{N}=441)$} & \multicolumn{2}{c|}{ Kontrollpersoner $(\mathrm{N}=451)$} \\
\hline Antall & Prosent & Antall & Prosent \\
\hline
\end{tabular}




\begin{tabular}{|c|c|c|c|c|}
\hline & \multicolumn{2}{|c|}{ Pasienter $(\mathrm{N}=441)$} & \multicolumn{2}{|c|}{ Kontrollpersoner $(\mathrm{N}=451)$} \\
\hline & Antall & Prosent & Antall & Prosent \\
\hline Gjennomsnittlig alder i år & 56,8 & & 56,6 & \\
\hline \multicolumn{5}{|l|}{ BMI } \\
\hline$<25 \mathrm{~kg} / \mathrm{m}$ & 219 & 49,7 & 196 & 43,5 \\
\hline $25-29 \mathrm{~kg} / \mathrm{m}$ & 164 & 37,2 & 179 & 39,7 \\
\hline$\geq 30 \mathrm{~kg} / \mathrm{m}$ & 51 & 11,6 & 67 & 14,9 \\
\hline Ukjent & 7 & 1,6 & 9 & 2,0 \\
\hline \multicolumn{5}{|l|}{ Paritet } \\
\hline 0 barn & 41 & 9,3 & 35 & 7,8 \\
\hline 1-2 barn & 249 & 56,5 & 255 & 56,5 \\
\hline$\geq 3$ barn & 150 & 34,0 & 161 & 35,7 \\
\hline Ukjent & 1 & 0,2 & 0 & 0,0 \\
\hline \multicolumn{5}{|l|}{ Alder ved første fødsel } \\
\hline$<25$ år & 234 & 53,1 & 259 & 57,4 \\
\hline$\geq 25$ år & 161 & 36,5 & 156 & 34,6 \\
\hline Ukjent & 5 & 1,1 & 1 & 0,2 \\
\hline \multicolumn{5}{|l|}{ Alder ved menarke } \\
\hline$<12$ år & 44 & 10,0 & 46 & 10,2 \\
\hline$\geq 12$ år & 387 & 87,8 & 401 & 88,9 \\
\hline Ukjent & 10 & 2,3 & 4 & 0,9 \\
\hline Mor med brystkreft & 46 & 10,4 & 37 & 8,2 \\
\hline \multicolumn{5}{|l|}{ Hormonbehandling } \\
\hline Aldri & 164 & 37,2 & 202 & 44,8 \\
\hline Før & 132 & 29,9 & 168 & 37,3 \\
\hline Noen gang & 277 & 62,8 & 249 & 55,2 \\
\hline Nå1 & 145 & 32,9 & 81 & 18,0 \\
\hline$\varnothing$ stradiol & 22 & 5,0 & 13 & 2,9 \\
\hline Kombinasjonspreparat & 99 & 22,4 & 45 & 10,0 \\
\hline Tibolon & 21 & 4,8 & 17 & 3,8 \\
\hline$\varnothing$ striol & 2 & 0,5 & 5 & 1,1 \\
\hline Progestagen & 1 & 0,2 & 1 & 0,2 \\
\hline [i] & & & & \\
\hline
\end{tabular}

[i] ${ }^{1}$ Kun systemisk behandling er inkludert 
En firedel av kvinnene var nåværende brukere. Av disse brukte $64 \%$

kombinasjonsbehandling. Brukere av østradiol alene utgjorde $15 \%$, mens tibolon ble brukt av $17 \%$. Blant brukerne var 219 (97\%) registrert som brukere i det forutgående spørreskjemaet. Av disse hadde 192 oppgitt alder ved start av hormonbehandling, og

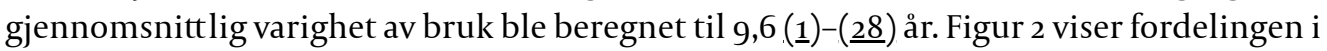
brukslengde blant nåværende brukere.

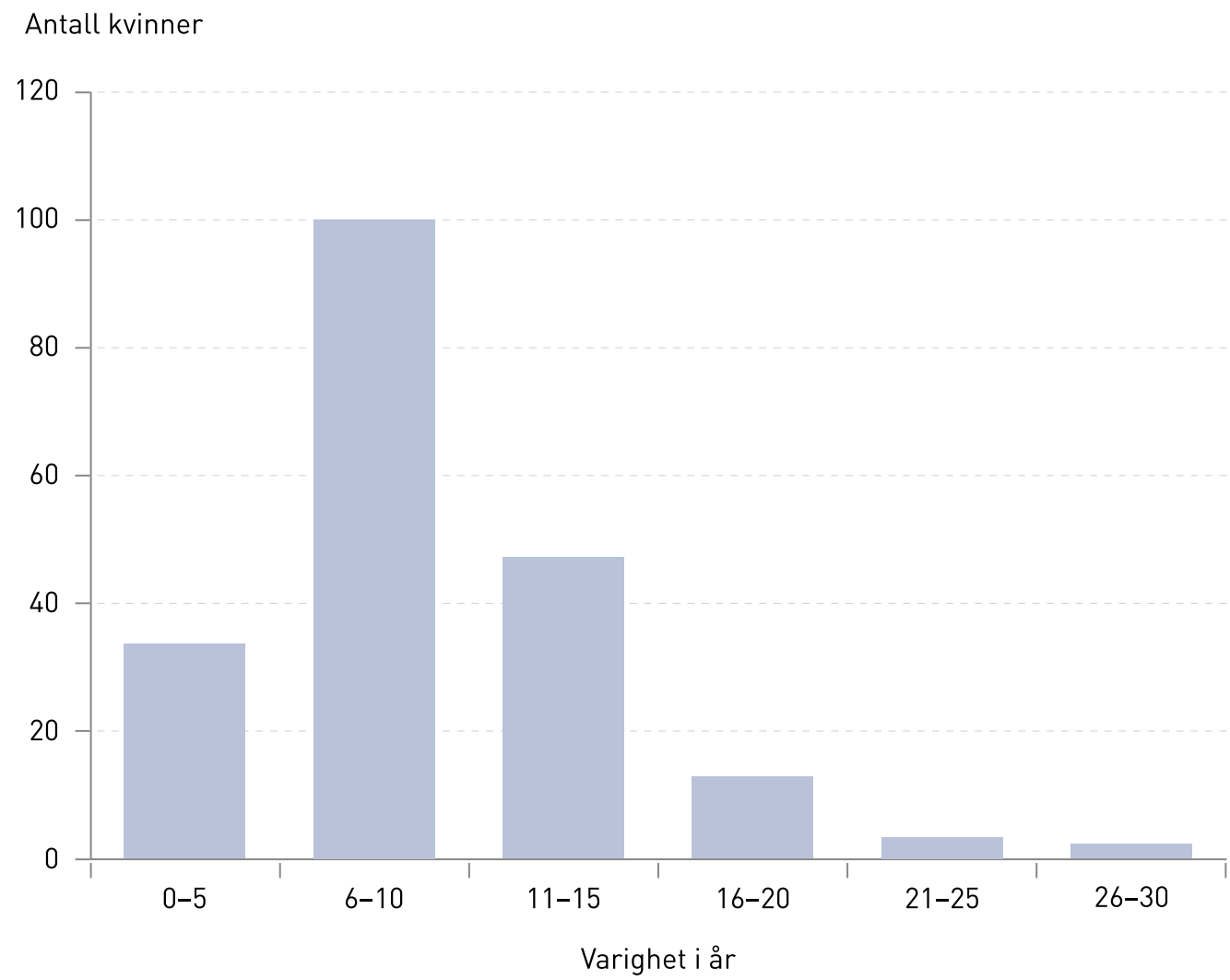

Figur 2 Nåværende brukere $(\mathrm{N}=192)$ av hormonpreparater (østrogener og progestagener, alene eller i kombinasjon) fordelt etter bruksvarighet Vi fant at justert risiko for brystkreft var signifikant høyere for nåværende brukere enn for aldri-brukere (oddsratio (OR) 2,1; 95 \% KI 1,5-3,0). Risiko var størst ved langvarig (> 5 år) behandling (OR 2,4; $95 \% \mathrm{KI}$ 1,6-3,6) (test for trend, p-verdi o,oo6, data ikke vist). Sammenliknet med aldri-bruk hadde brukere av kombinasjonsbehandling oddsratio 2,6 ( $95 \%$ KI 1,7-4,0), og for dem med bruk utover fem år var OR 3,0 (95\% KI 1,9-4,7). Bruk av østradiol eller tibolon ga lavere, ikke statistisk signifikant risiko, OR 1,8 (95\% KI o,9-3,8) og OR 1,5 (95\% KI o,8-3,0), men var basert på få brukere. «Noen gang»- brukere hadde generelt noe økt risiko (OR 1,3; $95 \%$ KI 1,0-1,7), mens tidligere bruk ikke ga forhøyet risiko (tab 2). Resultatene endret seg kun ubetydelig når vi så på invasiv brystkreft og carcinoma in situ samlet og hver for seg. Gjennomsnittlig oppfølgingstid (differansen mellom diagnosedato og dato for besvarelse av spørreskjema) var 1,9 (o-5) år. Risikoestimatene forholdt seg stabile i løpet av oppfølgingsperioden (data ikke vist).

\section{Tabell 2}

Oddsratio (OR) med $95 \%$ konfidensintervall (KI) for brystkreft ${ }^{1}$

\begin{tabular}{|lcc|}
\hline Bruk av hormoner & OR $(\mathbf{9 5} \% \mathrm{KI})$ & $\mathrm{OR}(\mathbf{9 5} \% \mathrm{KI})$ justert $^{2}$ \\
\hline Aldri & $1,0($ ref $)$ & $1,0($ ref $)$ \\
\hline Noen gang & $1,4(1,1-1,8)$ & $1,3(1,0-1,7)$ \\
\hline Før & $1,0(0,7-1,3)$ & $0,9(0,6-1,2)$ \\
\hline
\end{tabular}




\begin{tabular}{|lcc|}
\hline Bruk av hormoner & OR $(95 \% \mathrm{KI})$ & $\mathrm{OR}(95 \% \mathrm{KI})$ justert $^{2}$ \\
\hline Nå & $2,2(1,6-3,1)$ & $2,1(1,5-3,0)$ \\
\hline$\leq 5$ år & $1,5(0,9-2,6)$ & $1,5(0,9-2,7)$ \\
\hline$>5$ år & $2,6(1,8-3,7)$ & $2,4(1,6-3,6)$ \\
\hline Kombinasjonspreparat & $2,8(1,9-4,1)$ & $2,6(1,7-4,0)$ \\
\hline$\leq 5$ år & $2,1(1,0-4,2)$ & $2,1(1,0-4,4)$ \\
\hline$>5$ år & $3,1(2,0-4,6)$ & $3,0(1,9-4,7)$ \\
\hline Østradiol & $2,1(1,1-4,3)$ & $1,8(0,9-3,8)$ \\
\hline Tibolon & $1,5(0,8-3,0)$ & $1,5(0,8-3,0)$ \\
\hline$[i]$ & & \\
\hline
\end{tabular}

[i] ${ }^{1} 417$ pasienter og 434 kontrollpersoner med fullstendige data er inkludert

${ }^{2}$ Justert for alder, kroppsmasseindeks, alder ved menarke, brystkreft hos mor, paritet og alder ved første fødsel

\section{TILSKRIVBAR RISIKO I BEFOLKNINGEN}

Vi brukte prevalensen for nåværende bruk av hormonbehandling blant kontrollpersonene $(18,1 \%)$ og oddsratio 2,1 som risikoestimat til å beregne tilskrivbar risiko for brystkreft blant kvinner 47-63 år i perioden 2003-08. Vi fant at 16,6\% av krefttilfellene kunne tilskrives behandling med østrogenholdige preparater. Med utgangspunkt i insidenstall fra Kreftregisteret for perioden 2003-08 utgjør dette 232 brystkrefttilfeller årlig i aldersgruppen $45-64$ år.

\section{Diskusjon}

I vår studie hadde nåværende brukere av hormonbehandling 2-3 ganger økt risiko for brystkreft sammenliknet med aldri-brukere. Dette var i samsvar med den tidligere Kvinner og kreft-studien. Risikoen var høyest ved bruk av kombinasjonsbehandling utover fem år. Prevalens av bruk var halvert fra 2002 til 2008 og tilskrivbar risiko redusert tilsvarende fra $27 \%$ til 16,6\%. Dette innebærer likevel at 232 brystkrefttilfeller årlig i denne aldersgruppen kunne tilskrives hormonbruk. Til sammenlikning har European Prospective Investigation into Cancer and Nutrition (EPIC) samlet en kohort av postmenopausale kvinner fra ulike europeiske land, som alle ble fulgt opp for brystkreft. Man fant at nåværende bruk av østrogen og kombinasjonspreparater ga økt relativ risiko, hhv. 1,42 og 1,77 (13).

Gjennomsnittlig tid fra utfylt spørreskjema til diagnose var i vår studie under to år. Det er en svakhet at kontrollgruppen ikke har lengre oppfølgingstid, fordi noen kan utvikle kreft senere. Hormonbehandling kan ha en vekstfremmende effekt på kreftceller (14). Det kan være årsaken til at hormonbrukerne får diagnosen tidligere. Vår studie gir derfor ikke i seg selv grunnlag for å si at bruk av hormonpreparater gir økt livstidsrisiko for brystkreft. Imidlertid anses substitusjonsbehandling med hormoner etter overgangsalder som en kjent risikofaktor (15), og kombinasjonen østrogen-progestagen er av International Agency for Research on Cancer (IARC) klassifisert som et karsinogen for brystkreft (16 $)$.

Studien er en nøstet pasient-kontroll-studie, der eksposisjonsopplysningene er hentet inn forut for kreftdiagnosen. Hukommelsesskjevhet er derfor lite relevant. Vi har ikke tatt hensyn til at kvinnene kan ha endret type preparat underveis i behandlingen. Ekstern 
validering av Kvinner og kreft-kohorten har vist at det foreligger få kilder til seleksjonsskjevhet som hindrer generalisering av resultatene til den kvinnelige norske befolkningen eller som umuliggjør beregning av tilskrivbar risiko (17.).

Vi valgte å ta med pasienter som hadde fått påvist carcinoma in situ. Invasiv brystkreft og duktalt carcinoma in situ ser ut til å ha samme risikofaktorer og mekanisme for utvikling $(\underline{18})-(\underline{20})$. Analyseresultatene endret seg kun ubetydelig når vi ekskluderte kvinner med cancer in situ.

Studier fra flere land viser at nedgangen i bruk av hormonbehandling følges av en nedgang

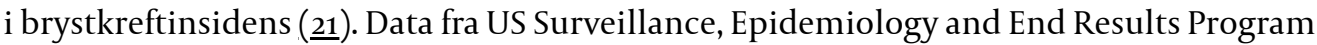
viste en nedgang i insidens fra 1999-2003 for dem over 45 år, overensstemmende med metningen i mammografiscreening. En skarp nedgang ble observert i perioden 2002-03 for østrogenreseptorpositive tumorer hos kvinner 50-69 år, noe som kan skyldes nedgangen i bruk av hormonbehandling (르).

I Norge økte brystkreftinsidensen i 1990-årene, for så å flate ut og falle svakt etter 2002 (fig 1). Innføringen av det norske mammografiprogrammet førte til at flere tumorer i stadium 1 ble oppdaget, særlig hos kvinner i alderen 50-69 år (23). Insidensøkningen kan likevel ikke alene forklares som en effekt av selve screeningen (24). En ny norsk studie har vist at endringene i insidens kan tilskrives mammografiscreening og hormonbehandling i nesten like stor grad (25). Hormonbehandling har sammenheng med $ø$ kt vevstett het $\mathrm{i}$ brystene (26). Kvinner som brukte eller nylig hadde brukt hormonbehandling hadde signifikant høyere gjennomsnittlig tetthet. Bruk av kombinasjonspreparater og langvarig bruk ga høyest tetthet. Økt mammografitetthet er en uavhengig risikofaktor for brystkreft (27.), og

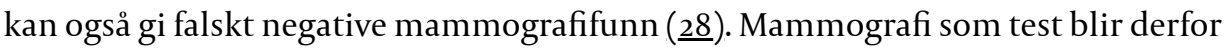
dårligere hos hormonbrukere.

Gjennomsnittlig brukslengde hos våre kvinner var nær ti år. Det er bekymringsfullt at eldre kvinner bruker hormonbehandling og at de forblir brukere, når vi vet at alder er en viktig risikofaktor og at risikoen for brystkreft øker for hvert år med hormonbehandling.

Ifølge en studie med data fra 2004 om norske allmennlegers holdninger til østrogenbehandling til kvinner i og etter overgangsalder var allmennleger flest kjent med effekter og bivirkninger. Hetetokter var viktigste indikasjon, og tidligere brystkreft og brystkreft hos førstegradsslektninger var kontraindikasjoner for behandling. Behandlingsvarighet var lenger enn det som er anbefalt. Studien indikerte for øvrig at kvinnelige leger var bedre faglig oppdatert, oftere hadde en regel for behandlingsvarighet og behandlet i kortere tid (29.). Studien viste også at norske leger var blitt mer restriktive i sin forskrivningspraksis, men anbefalinger om bruk varierte. Flere ville anbefale hormonbehandling ved lette, mindre plagsomme hetetokter dersom kvinnen enten hadde blødningsforstyrrelser eller følte seg nedfor, hadde aldersforandringer i huden og ikke var tilfreds med samlivet. De fleste ville verken anbefale eller fraråde behandling med utgangspunkt i forelagte kasuistikker. Jo eldre legene var, jo større var tendensen til å ville anbefale bruk (30).

Gjeldende retningslinjer sier at behandling med hormoner er aktuelt når kvinnens plager er uttalte og fører til redusert livskvalitet, alternativ behandling ikke har hatt effekt samt at fordelene veier opp for ulempene av behandling (31,32). Før hormonbehandling igangsettes skal det foretas en individuell vurdering, med en grundig anamnese som vektlegger kvinnens disposisjon for hormonsensitive kreftformer og hjerte- og karsykdom. Norsk gynekologisk forening har listet opp kontraindikasjoner for behandling (33). Andre risikofaktorer, som høy alder, sen menopause, overvekt, sen fødsel eller nulliparitet og høyt alkoholforbruk, mener vi bør tas med i vurderingen. Ifølge Legemiddelverket skal behandlingen revurderes årlig. Etter 2-3 år skal kvinnen nøye informeres om uheldige sideeffekter og «sammen med den behandlende lege gjøre en avveining mellom behovet for behandling og risikoen». Hormonbehandling skal ikke brukes ved blødningsforstyrrelser (31). 
Tibolon er en vevsspesifikk regulator med østrogen og androgen effekt og er det nyeste av hormonpreparatene som bedrer klimakterielle symptomer og forebygger osteoporose. Tibolon reduserer nivået av aktivt østrogen i brystvev og brystkreftceller og er vist å ha liten effekt på celleproliferasjon og brystvevstetthet (34.). Dermed skulle man forvente at bruk av tibolon var mer gunstig. Enkelte mindre studier har vist at tibolon reduserer risikoen for brystkreft (35), men store observasjonsstudier har vist det motsatte. Både i The Million Women og i EPIC-studien fant man økt risiko ved nåværende bruk av tibolon, henholdsvis RR 1,45 (1,25-1,67) og RR 1,95 (1,43-2,65) (7.). Før vi har større studier og mer kunnskap om langtidseffektene kan vi derfor ikke anbefale overgang til tibolon.

\section{Konklusjon}

Vi fant en gjennomsnittlig brukstid på ti år hos etablerte brukere av systemisk hormonbehandling. Langvarig bruk av østrogen og progestagen i kombinasjon gir tredoblet risiko for brystkreft. Det er bekymringsfullt at postmenopausale kvinner fortsetter behandlingen.

Studien viser at 232 tilfeller av brystkreft hos norske kvinner 46-63 år årlig kan tilskrives hormonbehandling.

Det er viktig at både leger og kvinner er godt informert om risiko ved behandling med systemiske østrogenholdige hormonpreparater. En grundig individuell risikovurdering bør ligge til grunn for oppstart av behandling, og gjeldende retningslinjer bør følges. For enkelte kvinner som er sterkt plaget av hetetokter er hormonbehandling stadig det mest effektive botemidlet vi har.

\section{LITTERATUR}

1. Wilson R. Feminine forever. New York, NY: M. Evans \& company, 1966.

2. Myhre E. Alltid kvinne. Er overgangsalderen en mangelsykdom? Oslo: Cappelen, 1976.

3. Stampfer MJ, Willett WC, Colditz GA et al. A prospective study of postmenopausal estrogen therapy and coronary heart disease. N Engl J Med 1985; 313:1044-9. [PubMed] [CrossRef]

4. Felson DT, Zhang Y, Hannan MT et al. The effect of postmenopausal estrogen therapy on bone density in elderly women. N Engl J Med 1993; 329: 1141-6. [PubMed] [CrossRef]

5. Hoover R, Gray LA Sr, Cole P et al. Menopausal estrogens and breast cancer. N Engl J Med 1976; 295 : 401-5. [PubMed] [CrossRef]

6. Rossouw JE, Anderson GL, Prentice RL et al. Risks and benefits of estrogen plus progestin in healthy postmenopausal women: principal results From the Women's Health Initiative randomized controlled trial. JAMA 2002; 288: 321-33. [PubMed] [CrossRef]

7. Beral V. Breast cancer and hormone-replacement therapy in the Million Women Study. Lancet 2003; 362: 419-27. Rettelse i: Lancet 2003; 362:116o. [PubMed] [CrossRef]

8. Bakken K, Alsaker E, Eggen AE et al. Hormone replacement therapy and incidence of hormonedependent cancers in the Norwegian Women and Cancer study. Int J Cancer 2004; 112:130-4. [PubMed] [CrossRef]

9. Sakshaug S, red. Legemiddelforbruket i Norge 2006-2010. Oslo: Folkehelseinstituttet, 2011.

10. Waaseth M, Bakken K, Lund E. Patterns of hormone therapy use in the Norwegian Women and Cancer study (NOWAC) 1996-2005. Maturitas 2009; 63: 220-6. [PubMed] [CrossRef]

11. Universitetet i Tromsø. Velkommen til Kvinner og kreft.

http://uit.no/ansatte/organisasjon/artikkel?

p_document_id=150476\&p_dimension_id=88111\&p_menu=42374(21.2.2012). 
12. Dumeaux V, Børresen-Dale AL, Frantzen JO et al. Gene expression analyses in breast cancer epidemiology: the Norwegian Women and Cancer postgenome cohort study. Breast Cancer Res 2008; 10: R13. [PubMed] [CrossRef]

13. Bakken K, Fournier A, Lund E et al. Menopausal hormone therapy and breast cancer risk: impact of different treatments. The European Prospective Investigation into Cancer and Nutrition. Int J Cancer 2011; 128:144-56. [PubMed] [CrossRef]

14. Gadducci A, Biglia N, Cosio S et al. Progestagen component in combined hormone replacement therapy in postmenopausal women and breast cancer risk: a debated clinical issue. Gynecol Endocrinol 2009; 25: 807-15. [PubMed] [CrossRef]

15. Hulka BS, Moorman PG. Breast cancer: hormones and other risk factors. Maturitas 2008; 61: 203-13. [PubMed] [CrossRef]

16. The International Agency for Research on Cancer (IARC). Combined Estrogen-Progestogen Contraceptives and Combined Estrogen-Progestogen Menopausal Therapy. Genève: IARC, 2007.

17. Lund E, Kumle M, Braaten T et al. External validity in a population-based national prospective study-the Norwegian Women and Cancer Study (NOWAC). Cancer Causes Control 2003; 14: 1001-8. [PubMed]

18. Reeves GK, Beral V, Green J et al. Hormonal therapy for menopause and breast-cancer risk by histological type: a cohort study and meta-analysis. Lancet Oncol 2006; 7: 910-8. [PubMed] [CrossRef]

19. Kerlikowske K. Epidemiology of ductal carcinoma in situ. J Natl Cancer Inst Monogr 2010; 2010: 139-41.

20. Farhat GN, Walker R, Buist DS et al. Changes in invasive breast cancer and ductal carcinoma in situ rates in relation to the decline in hormone therapy use. J Clin Oncol 2010; 28: 5140-6. [PubMed] [CrossRef]

21. De P, Neutel CI, Olivotto I et al. Breast cancer incidence and hormone replacement therapy in Canada. J Natl Cancer Inst 2010; 102:1489-95. [PubMed] [CrossRef]

22. Jemal A, Ward E, Thun MJ. Recent trends in breast cancer incidence rates by age and tumor characteristics among U.S. women. Breast Cancer Res 2007; 9: R28. [PubMed] [CrossRef]

23. Hofvind S, Sørum R, Haldorsen T et al. Brystkreftforekomst før og etter innføring av mammografiscreening. Tidsskr Nor Lægeforen 2006; 126: 2935-8. [PubMed]

24. Bakken K, Lund E, Eggen AE. The impact of hormone replacement therapy on the incidence of breast cancer in Norway. J Clin Oncol 2005; 23:3636-7. [PubMed] [CrossRef]

25. Weedon-Fekjær H, Bakken K, Vatten LJ et al. Understanding recent trends in incidence of invasive breast cancer in Norway: age-period-cohort analysis based on registry data on mammography screening and hormone treatment use. BMJ 2012;344: e299. [PubMed] [CrossRef]

26. Bremnes Y, Ursin G, Bjurstam N et al. Different types of postmenopausal hormone therapy and mammographic density in Norwegian women. Int J Cancer 2007; 120: 880-4. [PubMed] [CrossRef]

27. Garrido-Estepa M, Ruiz-Perales F, Miranda J et al. Evaluation of mammographic density patterns: reproducibility and concordance among scales. BMC Cancer 2010;10:485. [PubMed]

28. Nothacker M, Duda V, Hahn M et al. Early detection of breast cancer: benefits and risks of supplemental breast ultrasound in asymptomatic women with mammographically dense breast tissue. A systematic review. BMC Cancer 2009; 9:335. [PubMed] [CrossRef]

29. Gjelsvik B, Swensen E, Hjortdahl P. Allmennlegenes syn på hormonbehandling i og etter overgangsalderen. Tidsskr Nor Lægeforen 2007; 127:1500-3. [PubMed]

30. Gjelsvik B. Allmennlegers råd om hormonbehandling i overgangsalderen. Tidsskr Nor Lægeforen 2008; 128: 1660-3. [PubMed]

31. Statens legemiddelverk. Hormontilskudd til kvinner etter menopausen gir $\emptyset \mathrm{kt}$ risiko for brystkreft. www.slv.no/templates/InterPage 16066.aspx (14.2.2012).

32. Norsk legemiddelhåndbok. T14.3 Klimakteriske besvær.

http://legemiddelhandboka.no/Terapi/søker/hormonbehandling/19o76\#i19126 (16.2.2012).

33. Norsk gynekologisk forening. Klimakteriet 2010.

http://legeforeningen.no/fagmed/norskgynekologisk-forening/veiledere/veileder-igenerellgynekologi-2009/klimakteriet-2010/(21.2.2012).

34. Notelovitz M. Postmenopausal tibolone therapy: biologic principles and applied clinical practice. MedGenMed 2007; 9: 2. [PubMed]

35. Opatrny L, Dell'Aniello S, Assouline S et al. Hormone replacement therapy use and variations in the risk of breast cancer. BJOG 2008; 115: 169-75. [PubMed] [CrossRef] 
Publisert: 12. juni 2012. Tidsskr Nor Legeforen. DOI: 10.4045/tidsskr.11.1055

Mottatt 17.9. 2011, første revisjon innsendt 22.2. 2012, godkjent 22.3. 2012. Medisinsk redaktør Jon Amund Kyte.

(C) Tidsskrift for Den norske legeforening 2023. Lastet ned fra tidsskriftet.no 26. april 2023. 